\title{
THE REV. G. U. POPE, D.D.
}

WHEN I was asked to write a short obituary notice of Dr. Pope, my esteemed guru in Dravidian studies, I was reminded of what he once said to me: "It is not in play, but in the performance of useful work, that a true man derives the greatest pleasure." This shows the bent of his mind. To do useful work was the great aim and pleasure of his life, and his success in it by his achievements, both as a missionary and as a student of research, is well known to the world.

He was born in Nova Scotia (Prince Edward Island) on the 24th of April, 1820, and was trained in a Wesleyan College for mission work in India, but later joined the Church of England. He arrived in India in 1839, took priest's orders at Madras in 1845, and for 42 years worked as a missionary in the Tamil country. In October, 1885, after his return to England, he was appointed Lecturer in Tamil and Telugu at Oxford. He died on the 11th of February last, after a short illness of two or three days. His eminent services in the cause of education and the propagation of Christianity in Southern India, and the reverence in which he was held by the people among whom he laboured, are too well known to need mention here. His numerous pupils and admirers have from time to time and in various ways shown their appreciation of his labours. It was only the other day that he was the happy recipient of an address and a presentation from them. He was, indeed, a model missionary. He loved his people and the people loved him. It was no doubt this spirit, rather than the mere exigencies of mission work, that led him to a thorough study of Dravidian literature.

So early as 1842, hardly three years after his arrival in India, he published his "First Catechism of Tamil Grammar"; in 1844, "The Second Catechism." These 
were followed by "The Third Catechism," including an edition of Nannūl, "A Tamil Handbook for English Students," in three parts, "A Tamil Prose Reader," and "A Tamil Poetical Anthology." His Oxford appointment and his election to an honorary fellowship at Balliol College gave a fresh impetus to his literary labours. In 1886 he brought out an edition of the Kural with an English translation; in 1893, the Nālaḍiyār ; and in 1900, his monumental work-a critical edition, with an English translation, of the Tiruvāçagam. These volumes do not represent even a tithe of his work, for besides a short history of India and contributions on Indian topics to various periodicals he left behind in MS. complete editions and English translations of the Paramori, the Çilappadigäram, and the Manimegaläi, as well as a vast amount of material for a standard Tamil dictionary.

He received the triennial Gold Medal of the Society in June, 1906, in recognition of his distinguished services to Indian research, and in pp. 767-790 of the Journal for that year will be found a detailed account of his life-work.

M. DE Z. WiCKREMASINGHE.

HENRIK EMILE HERBERT BORGSTRÖM, M.R.A.S.

IN the death of Henrik Emile Herbert Borgström, of Turholm Park, and Trikant, Helsingfors, on the 19th of November, 1907, Finland lost one of her most accomplished sons, and the British Royal Asiatic Society one of its most promising young members. $\mathrm{He}$ was only in his 34th year, yet his acquirements as a philologist and deep philosophic thinker attracted and astonished all who met him and were capable of following his brilliant conversation and comprehending his field of thought. He spoke and wrote every literary language of modern Europe perfectly, and was a devoted student 